\title{
Reading Comprehension and Reading Speed of University English Language Learners in Ecuador
}

\author{
Juan F. Mora ${ }^{1} \square$ Isabel R. Quito ${ }^{2}$ and Louis E. Macías ${ }^{3}$ \\ ${ }^{123}$ Departamento de Idiomas, Universidad de Cuenca, Ecuador \\ $\square$ Corresponding Author: Juan F. Mora, E-mail: fernando.mora@ucuenca.edu.ec
}

\begin{tabular}{ll}
\hline ARTICLE INFORMATION & ABSTRACT \\
\hline $\begin{array}{l}\text { Received: } 01 \text { September } 2021 \\
\text { Accepted: } 25 \text { September } 2021\end{array}$ & $\begin{array}{l}\text { Reading represents a significant skill for knowledge acquisition. Nevertheless, many } \\
\text { people cannot read properly, which may entail a serious limitation to their study, work, } \\
\text { Published: } 16 \text { October } 2021\end{array}$ \\
DOI: $10.32996 / j e l t a l .2021 .3 .11 .3$ & $\begin{array}{l}\text { or other aspirations. The purpose of this research work is to determine the reading } \\
\text { comprehension level and reading speed of English language students at the University } \\
\text { of Cuenca, Ecuador, as well as the impact of sociodemographic factors and the use of } \\
\text { reading strategies on these levels. The participants were } 400 \text { students who were taking }\end{array}$ \\
\hline KEYWORDS & $\begin{array}{l}\text { English courses during September } 2019 \text { to February } 2020 \text { semester. The students } \\
\text { completed a questionnaire on sociodemographic factors, took reading tests to } \\
\text { Reading comprehension, reading }\end{array}$ \\
speed, English as a foreign & $\begin{array}{l}\text { questionnaire on reading strategies. The results show a high level of reading } \\
\text { language, reading strategies }\end{array}$ \\
comprehension in English but a below-average reading speed, in part due to certain \\
external factors. Given these results, research-based intervention is highly \\
recommended to improve reading levels.
\end{tabular}

\section{Introduction}

The access to knowledge in formal learning is mostly enabled by audio-visual materials, and a significant portion of that knowledge is acquired through reading (Escurra, 2003; Vallés, 2005). When dealing with higher education, this occurs through academic reading in particular (Hermida, 2009). Reading is a complex activity comprising psychological, linguistic, and sociological aspects; it is an interactive process between the reader and the text in which the reader gives the latter meaning (Shihab, 2011). According to Carrell and Eisterhold (1983), reading is a guessing game in which readers reconstruct the message coded by writers. For Sparks et al. (2009), sensory skills like vision and hearing are enhanced through reading expertise, which together with the acquisition of the habit of reading, build up a series of elements such as the use of reasoning skills. This involves the development of cognitive skills like critical thinking, understanding, analysis, synthesis, inference, and value judgments, which increase the probability of becoming a proficient reader (Halpern, 2014; Vallés, 2002, 2005; Yeh and Chen, 2005).

\section{Literature Review}

Research into reading and comprehension skills is extensive. According to Anderson and Pearson (1984), reading comprehension is defined as a process in which the reader produces meaning by interacting with the text; this interaction comes from previous experiences when the words, phrases, paragraphs, or ideas of the author are decoded. Therefore, the knowledge of vocabulary, concepts, and structural elements of the text, as well as the reader's existing knowledge, contribute to a successful understanding (Schutz, 2010; Snow, 2002). In the first years of schooling, an individual is taught to read; once this is achieved, they are expected to read to acquire knowledge, and this can only be accomplished with accurate reading habits, regardless of the mother tongue of the reader. The knowledge of vocabulary is a crucial factor in reading comprehension in both a first language (L1) (National Reading Panel, 2000) and second language (L2) or foreign language (lqbal, Noor, and Kazemian, 2015; Laufer, 1989; Nation, 2001). With regard to reading skills in an $\mathrm{L} 2$ or foreign language, factors that negatively influence reading comprehension includes poor management of vocabulary, tenses, and grammar structures, emphasis on passing an exam instead of developing the skill, a lack

Copyright: (C) 2021 the Author(s). This article is an open access article distributed under the terms and conditions of the Creative Commons Attribution (CC-BY) 4.0 license (https://creativecommons.org/licenses/by/4.0/). Published by Al-Kindi Centre for Research and Development, London, United Kingdom. 
of knowledge of reading strategies, and a lack of reading habits (lqbal et al., 2015). According to Anderson (1991) and Bongratz et al. (2002), readers who effectively use a higher number of strategies achieve better results in reading comprehension tasks.

Another essential aspect of reading skill is speed, which refers to the number of words a person can read correctly in a specific amount of time. This speed varies according to the type of reading performed. Fry (1975) suggests three levels: 1) common reading (magazines, books, simple texts): 250-500 words per minute (wpm) with a 70\% comprehension level; 2) study reading (complex texts that demand deep concentration): 180-200 wpm with $90 \%$ comprehension; and 3) superficial reading (text exploration): 800 wpm with $50 \%$ comprehension. In general, the rapid reading of a text is essentially the reflection of a good level of automatism in word recognition (López, 2013). Thus, some studies indicate that the average reading speed of a skillful reader in their mother tongue is between 250 and $300 \mathrm{wpm}$, but in L2 or in a foreign language this average drops to 200-250 wpm (Nation, 2005) when the reading material includes vocabulary and grammatical structures known by the student (Nation, 2009). Additionally, a drop in the average wpm in L2 or foreign language occurs because of the presence of vocabulary and grammar unknown by the reader or because the purpose of reading is not designed for skimming through (Cobb, 2008; Fraser, 2007).

There is a very close relationship between reading speed and reading comprehension. Contrary to what is believed-that the slower the reading, the greater the comprehension-studies have shown that if a person displays a high level of reading comprehension, it is likely that their reading speed will be high as well (Bowey, 2005; Perfetti, Landi, and Oakhill, 2005; Snow, Burns, and Griffin, 1998; Stanovich, 2000). Moreover, intervention research conducted in these two areas shows that when students receive training to improve their reading speed, they also improve their level of reading comprehension (Alessi and Dwyer, 2008; Chang, 2010; Nicholson and Tan, 1999; Segalowitz and Segalowitz, 1993). When a person shows a good level of reading speed and reading comprehension in their mother tongue, something similar usually happens in the target language, based on the averages indicated previously. This is explained by the linguistic interdependence hypothesis (Cummins, 1981), which suggests that L1 skills are transferred to L2 skills. That is, a person's level of reading, writing, listening, and speaking in their first language will be similar when using a second or foreign language. In this context, a good level of reading skill may also depend on other factors such as, for instance, a person's reading habits, i.e., if someone often reads books, magazines, articles, etc., they are expected to be fast readers as well as show a high level of comprehension (Francisco and Madrazo, 2019; Septiarini, Rahmat, and Darmahusni, 2018; Suhana and Haryudin, 2017).

A very important issue in the context of speed and comprehension is the use of reading strategies, which might lead a person to read faster or slower or to understand more or less of what they read. A number of authors have developed different questionnaires to identify and/or evaluate reading comprehension strategies. Among these authors, Mokhtari and Reichard (2002) designed the Metacognitive Awareness of Reading Strategies Inventory (MARSI), an instrument 'to assess adolescent and adult readers' metacognitive awareness and perceived use of reading strategies while reading academic or school-related materials" (p. 249). This questionnaire was the foundation for the generation of the Survey of Reading Strategies (SORS) by Mokhtari and Sheory (2002), an upgraded version of the previous instrument. According to Mokhtari and Sheory (2002), there are three kinds of reading strategies: global, problem-solving, and support. Global strategies (GLOB) "are those intentional, carefully planned techniques by which learners monitor or manage their reading" (p. 4), such as predicting what the subject of the text will be, confirming predictions, or making decisions regarding what needs to be read more carefully. Problem-solving strategies (PROB) "are the actions and procedures that readers use while working directly with the text" (p. 4). More specifically, these are strategies for solving problems when reading a text becomes too difficult, such as reading more slowly, rereading, or reading out loud. Finally, support strategies (SUP) "are basic support mechanisms intended to aid the reader in comprehending the text" (p. 4), such as taking notes, underlining, or writing summaries. Reading strategies can be used before, during, and/or after reading; this will depend on the type of text and/or the participants' decisions regarding what strategy to use and when each works best for them.

The importance of reading strategies lies in the fact that the more frequent their use the better is the comprehension of a text (Abdelrahman and Bsharah, 2014; Abdullah, 2018; Anderson, 1991; Bongratz et al., 2002; Grabe, 2009; Pressley, 2006; Uribe-Enciso, 2015). With regard to speed, the two most common strategies that lead to faster reading are skimming and scanning (Abdelrahman and Bsharah, 2014; Abdullah, 2018). Skimming is reading a text quickly to get the main idea, while scanning is doing the same but with the objective of getting specific information. Therefore, both strategies involve not reading every single word in the text, and in this way, readers do not waste time, which results in an increase in their reading speed (when reading silently). In this regard, Beale (2013) states that "people who know how to skim and scan are flexible readers. They read according to their purpose and get the information they need quickly without wasting time. They do not need to read everything, which increases their reading speed. Their skill lies in knowing what specific information to read and which method to read" (p. 1). In sum, the constant use of certain reading strategies helps a person comprehend a text better and when a person effectively uses a number of strategies 
when reading (like skimming and scanning), their speed tends to increase as well (Abdelrahman and Bsharah, 2014; Barzegar and Fazilatfar, 2019).

A number of studies indicate that certain sociodemographic factors might have an effect on the reading performance of individuals. Gender is one of the variables that has been found to have a significant impact on reading comprehension, reading speed, and reading strategies. In some case studies, women outperformed men in reading comprehension (Fauzan, 2016; Reiily, Neumann, and Andrews, 2019) and reading speed (Emma and Yousef, 2012). However, in others, no statistically significant differences were found (Hussein, 2018; Poole, 2005). According to Goh and Kwah (1997) and Hong-Nam and Leavell (2006), women use more reading strategies and do so more frequently than men, particularly compensation and effective strategies. Nevertheless, Poole (2005) and Ismail, Karim, and Mohamed (2018) state that the use of reading strategies might be influenced by certain factors other than gender. On the other hand, Chen and Wu (2017) and Miñoza and Montero (2019) found that the socioeconomic status (SES) of their family might have an impact on the reading performance of children: those with higher incomes develop better reading skills than those with lower incomes since the latter tend to lack access to a variety of reading materials. A study by Ismail, Karim, and Mohamed (2018), however, did not find any relationship between SES and reading performance. In sum, it seems that there are no definite sociodemographic factors that regularly have an influence on the reading performance of individuals; some factors are statistically significant in some cases but are not in others. It seems that the variation in the type of study participants plays a role: each population studied has its own particular characteristics and, therefore, study results are mixed.

In spite of this, studies on the aforementioned reading skills and the impact of sociodemographic factors are still scarce, particularly in reference to local university students, and even less in the context of learning English as a foreign language. Therefore, the research questions addressed in this study are as follows:

1. What is the reading comprehension level and reading speed of English language students at the University of Cuenca?

2. To what extent does the use of reading strategies affect the level of English reading comprehension of learners?

3. What sociodemographic factors have an effect on the reading comprehension level, reading speed, and use of strategies by English language students at the University of Cuenca?

\section{Methodology}

\subsection{Participants and context}

The participants were 400 students taking English language courses at the University of Cuenca, Ecuador, during the September 2019-February 2020 term. The University of Cuenca is a public university located in the southern area of the country and is the sixth-largest university in Ecuador. It comprises a population of around 16,000 students divided into 12 schools and 5 campuses. Students have to pass three English language levels equivalent to the A1, A2, and B1 levels of the Common European Framework of Reference for Languages (CEFR) as a mandatory requirement for all majors. These courses are provided by the Language Department of the University of Cuenca, an academic unit that also offers courses in English and other languages for the general public. These are called intensive courses and feature levels A1-B2. Some students of these English language courses took part in the study as well.

The average age of the sample population was 22.94 years: $60.25 \%$ were female and $39.75 \%$ were male students; $90.25 \%$ of the students were single; $81.5 \%$ were taking mandatory courses, while the remaining $18.5 \%$ were students of courses offered to the general public. Table 1 summarizes the sociodemographic profile of participants.

Table 1. Participant sociodemographic profiles

\begin{tabular}{llcc}
\hline Parameter & Group & n & \% \\
\hline Age & Average age (22.94 years) & 400 & 100.00 \\
\hline \multirow{2}{*}{ Gender } & Female & 241 & 60.25 \\
& Male & 159 & 39.75 \\
\hline \multirow{2}{*}{ CEFR level } & A1 & 125 & 31.25 \\
& A2 & 206 & 51.50
\end{tabular}




\begin{tabular}{llcl} 
& B1 & 55 & 13.75 \\
& B2 & 14 & 3.50 \\
\hline \multirow{2}{*}{$\begin{array}{l}\text { School or field } \\
\text { of specialization }\end{array}$} & Architecture and Urbanism & 2 & 0.50 \\
& Art & 29 & 7.25 \\
& Agricultural Sciences & 58 & 14.50 \\
& Chemical Sciences & 20 & 5.00 \\
& Dentistry & 10 & 2.50 \\
& Econ. and Admin. Sciences & 40 & 10.00 \\
& Engineering & 32 & 8.00 \\
& Jurisprudence and & & \\
& Political and Social Sciences & 43 & 10.75 \\
& Medical Sciences & 82 & 20.50 \\
& Philosophy and Ed. Science & 48 & 12.00 \\
Psychology & 18 & 4.50 \\
High school graduates & 16 & 4.00 \\
\hline
\end{tabular}

\subsection{Data collection}

In order to uncover potential correlations between the reading skills of participants and factors such as their age, gender, English language proficiency, and university major, among other personal data, the students first completed a sociodemographic questionnaire. Then they took a reading speed and comprehension test. To determine their competence in these skills, the web page $w w w$.freereadingtest.com was used. This is a free service provided by the research and development company StepWare, Inc., which developed AceReader, a reading speed, comprehension, and fluency software program. This test was chosen after an analysis of at least six sites with similar characteristics. The instrument presents a series of texts on history, science, and current issues, featuring 13 levels of difficulty and three topics for each level. In the last twenty years, AceReader has been applied to different groups, both at a middle and higher level of education, with highly reliable results (Snead, 2005; Willingham, 2017).

Before administering the tests to determine speed and reading comprehension, these were piloted to ensure that the vocabulary and difficulty of the selected texts were in agreement with participants' English language proficiency. For this purpose, the readings were analyzed and compared to the parameters with which performance in the acquisition of a foreign language is categorized according to the CEFR, that is, into levels $A 1, A 2, B 1, B 2, C 1$, and $C 2$. As a result, 12 readings (Appendix 1) were selected for the tests (three for each of the levels except $\mathrm{C} 1$ and $\mathrm{C} 2$ because these are not offered by the Language Department at the University of Cuenca). The protocol for administering these tests was as follows:

1. The students browsed the website www.freereadingtest.com and read three passages previously selected according to their English level proficiency.

2. After reading the passages, the students answered four comprehension questions for each passage. The average reading speed of an adult in a second language is between 200 and $250 \mathrm{wpm}$. If a student's reading speed is slower than this, their level is considered insufficient and the student is deemed to require support to improve their speed; if they reach a higher number of wpm than the average, they are considered advanced readers. The level of understanding of each text can be $0 \%, 25 \%, 50 \%, 75 \%$, or $100 \%$. If a student obtains $0 \%$, they are considered to have an insufficient level of comprehension; $25 \%$ is considered regular comprehension; $50 \%$ is a good level; $75 \%$ is very good, and $100 \%$ is outstanding. In sum, by averaging out the results, if a participant manages to read between 200 and 250 wpm with a reading comprehension of at least $50 \%$, they are considered average 
second language readers. Testing at lower values means that the student has reading difficulties while getting higher values means that they have advanced reading skills.

After the reading tests, the participants completed a questionnaire on reading strategies (Pereira and Ramírez, 2006) that was based on the Survey of Reading Strategies (SORS) by Mokhtari and Sheory (2002) (Appendix 2). The questionnaire was in Spanish so as to allow the students, and especially those with only basic proficiency in the target language, to feel confident enough to fully understand the questions and provide suitable answers. This survey featured 24 questions intended to measure the type and frequency of strategies the participants use when reading in English as a second language. Each of the questions used a 5-point Likert scale, ranging from 1 (I always or almost always do this) to 5 (I never or almost never do this). After reading each statement, the participants selected the number that applies to them. This number indicates the frequency with which they use the strategy mentioned in the statement. The reading strategies measured in the survey were global, problem-solving, and supporting strategies (these are explained in detail in the Introduction). After scoring the questionnaire, three levels of reading strategy use can be identified: high (mean of 3.5 or higher), moderate (mean of 2.5 to 3.4), and low (mean of 2.4 or lower). This questionnaire was administered after the reading speed and comprehension tests so that the participants could provide answers based on the material they read a few minutes before.

\section{Results and Discussion}

The average reading speed and comprehension of the participants are shown in Table 2. The average reading speed was 142 wpm, meaning that the students have a low reading speed and require additional support. However, their average reading comprehension was $80 \%$, above the minimum of $75 \%$ (a very good level of understanding). This might imply that the students focused on understanding the texts well enough to be able to answer the comprehension questions correctly, resulting in slow reading.

Table 2. Average reading speed and comprehension.

\begin{tabular}{lcc}
\hline & Reading speed & Reading \\
& wpm & $\%$ \\
& 142 & 80 \\
Reading 1 & 149 & 80 \\
Reading 2 & 135 & 79 \\
Reading 3 & 142 & 80 \\
\hline Average & &
\end{tabular}

In order to determine whether there is a correlation between the average reading speed and reading comprehension of the participants, the non-parametric Spearman's rank correlation test was used; however, the results show that there is no relationship between the aforementioned variables.

Table 3. Spearman's correlation matrix between reading speed and reading comprehension.

\begin{tabular}{|c|c|c|c|c|}
\hline Correlations & & & $\begin{array}{l}\text { Reading comprehension } \\
(\%)\end{array}$ & $\begin{array}{l}\text { Reading } \\
\text { speed }\end{array}$ \\
\hline \multirow{6}{*}{$\begin{array}{l}\text { Spearman's } \\
\text { Rho }\end{array}$} & \multirow{3}{*}{$\begin{array}{l}\text { Reading } \\
\text { comprehension (\%) }\end{array}$} & $\begin{array}{l}\text { Correlation } \\
\text { coefficient }\end{array}$ & 1.000 & 0.032 \\
\hline & & Sig. (2-tailed) & & 0.522 \\
\hline & & $\mathrm{N}$ & 400 & 400 \\
\hline & \multirow{3}{*}{ Reading speed } & $\begin{array}{l}\text { Correlation } \\
\text { coefficient }\end{array}$ & 0.032 & 1.000 \\
\hline & & Sig. (2-tailed) & 0.522 & \\
\hline & & $\mathrm{N}$ & 400 & 400 \\
\hline
\end{tabular}


The participants were grouped according to their A1, A2, B1, and B2 CEFR levels. Table 4 shows the average reading speed and reading comprehension according to language proficiency. The results indicate that the A1-level participants achieved the best results in terms of speed, with $188 \mathrm{wpm}$, and the B1-level participants achieved the highest level of reading comprehension (83\%), while the B2-level participants, with 84 wpm and 66\% comprehension, obtained the lowest scores.

Table 4. Average reading speed and comprehension by proficiency level.

\begin{tabular}{lll}
\hline & Reading speed (wpm) & Reading comprehension (\%) \\
\hline A1 & Mean & Mean \\
A2 & 187.95 & 79.73 \\
B1 & 120.50 & 79.53 \\
B2 & 132.23 & 82.73 \\
\hline
\end{tabular}

Figure 1 below shows the average reading speed and comprehension by school or field of specialization, which is grouped in different areas of knowledge. The evidence indicates that the participants reading the fastest were in the fields of agricultural sciences and biosciences, while those reading the slowest were in the exact mathematical sciences. The level of reading comprehension was quite similar in all areas. The results concerning reading speed, however, cannot be considered conclusive since the number of participants was different in each of the areas of knowledge. We will discuss this issue in more detail in the discussion section.

Figure 1. Average reading speed and comprehension by school or field of specialization.

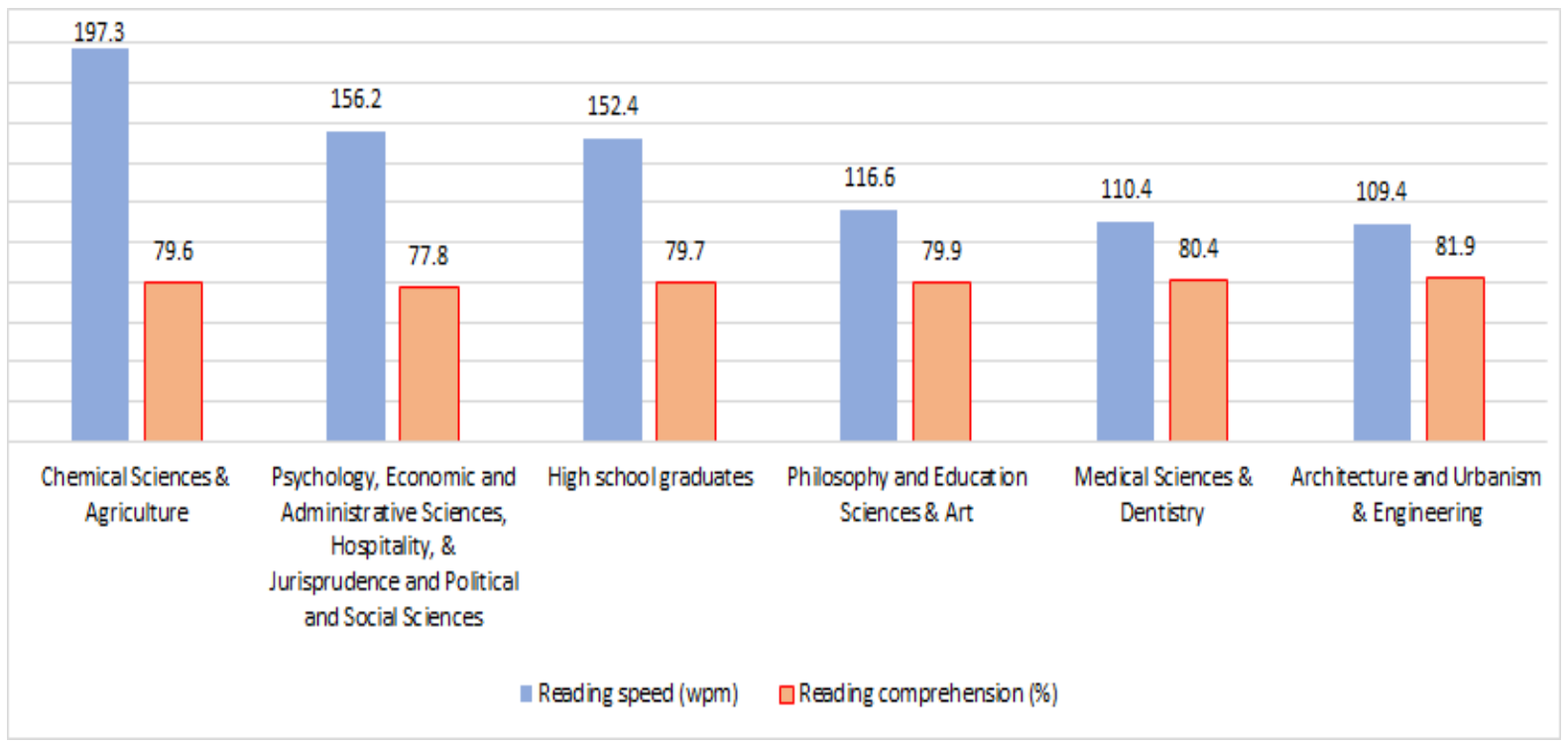

In order to determine the relationship between age and reading speed and comprehension, the non-parametric Spearman's rank correlation test was used. The results show that there is a negative association between age and reading comprehension, meaning that the older the learner is, the lower their comprehension. With regard to reading speed, there is no evidence of an association with the age of the participants.

Table 5. Correlation coefficients between age and reading speed and comprehension. 


\begin{tabular}{|c|c|c|c|c|c|}
\hline \multicolumn{3}{|l|}{ Correlations } & Reading comprehension (\%) & Reading speed (wpm) & Age \\
\hline \multirow{3}{*}{ Spearman's Rho } & Age & Correlation coefficient & $-0.113^{*}$ & 0.025 & 1.000 \\
\hline & & Sig. (2-tailed) & 0.024 & 0.612 & \\
\hline & & $\mathrm{N}$ & 400 & 400 & 400 \\
\hline
\end{tabular}

* Correlation is significant at the 0.05 level (2-tailed).

On average, women read 136 wpm and achieved $80 \%$ comprehension, while men read 150 wpm and achieved $79 \%$ comprehension. A mean difference test was used in order to uncover any significant differences between men and women. The results show that men read faster than women; however, their average reading comprehension was the same.

Table 6. Gender differences in reading speed and comprehension.

\begin{tabular}{lll}
\hline Test Statistics & $\begin{array}{l}\text { Reading } \\
\text { speed }\end{array}$ & $\begin{array}{l}\text { Reading } \\
\text { comprehension }\end{array}$ \\
\hline Mann-Whitney U & $16,030.500$ & $18,557.000$ \\
Wilcoxon W & $45,191.500$ & $31,277.000$ \\
Z & -2.765 & -0.541 \\
Asymp. Sig. (2-tailed) & 0.006 & 0.589 \\
\hline
\end{tabular}

a Grouping variable: Participant gender.

The type of high school the learners attended prior to their university studies (public, private, or charter) could have had an impact on the results of this study. Figure 2 below shows that the students from private institutions obtained the best results regarding reading speed (174 wpm), 31 more words than those who studied in a public institution, and 81 more than students from charter schools. Their reading comprehension levels, on the other hand, were about the same.

Figure 2. Average reading speed and comprehension according to the type of high school (public, private, or charter).

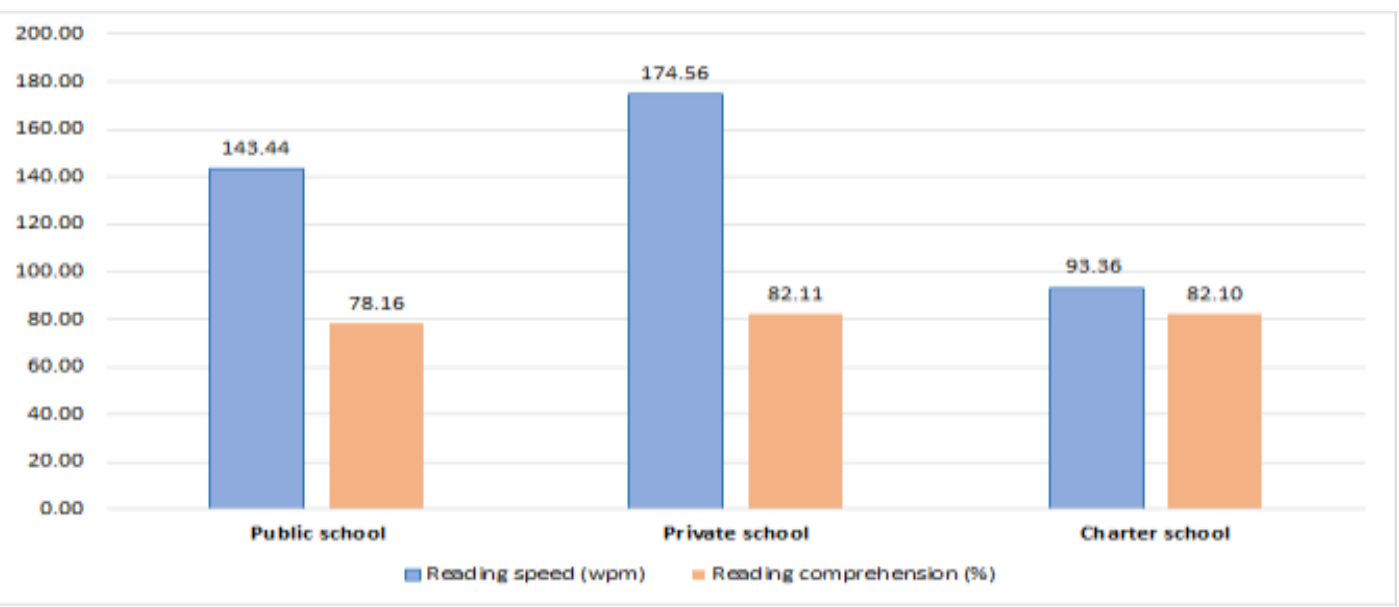

The income of participants is another variable that may play a role. Table 7 indicates the correlation between the students' income and their average reading speed and comprehension levels. The results show that there is no evidence of an association of any kind. 
Table 7. Association between participant income and reading speed and comprehension.

\begin{tabular}{|c|c|c|c|c|}
\hline \multicolumn{3}{|l|}{ Correlations } & \multirow{2}{*}{$\begin{array}{l}\text { Reading } \\
\text { speed } \\
\text { (wpm) }\end{array}$} & \multirow{2}{*}{$\begin{array}{l}\text { Reading } \\
\text { comprehension } \\
(\%)\end{array}$} \\
\hline $\begin{array}{l}\text { Spearman's } \\
\text { Rho }\end{array}$ & Income & $\begin{array}{l}\text { Correlation } \\
\text { coefficient }\end{array}$ & & \\
\hline & & Sig. (2-tailed) & 0.187 & 0.965 \\
\hline & & $\mathrm{N}$ & 400 & 400 \\
\hline
\end{tabular}

Another variable that might have a bearing on the average reading speed and comprehension level is the use of reading strategies. As stated in the Introduction, their effective and frequent use may lead a person to read and comprehend more than those who do not. Mokhtari and Sheory (2002) established three kinds of reading strategies: global (GLOB), problem-solving (PROB), and supporting (SUP). Table 8 indicates that the participants in this study show high use of all of these strategies, and particularly PROB strategies, which show a mean of 4.27 out of 5 points.

Table 8. Use of reading strategies.

\begin{tabular}{lcc}
\hline $\begin{array}{l}\text { Type } \\
\text { strategy }\end{array}$ & Mean & Percentage \\
\hline GLOB & 3.56 & $71.11 \%$ \\
PROB & 4.27 & $85.38 \%$ \\
SUP & 3.50 & $70.05 \%$ \\
\hline Average & 3.75 & $74.88 \%$ \\
\hline
\end{tabular}

Table 9 portrays the distribution of strategy usage by the participants in the study. As can be seen, the five top strategies are PROB strategies, ranging from 4.31 points (item 1: Try to get back on track) to 4.43 points (item 5: Reread the text to increase understanding). On the other hand, the five lowest scores include two GLOB strategies (item 20, 3.20 points: Decide what to read closely and what to ignore, and item 24, 2.93 points: Preview the text before reading), two SUP strategies (item 22, 3.16 points: Ask myself questions while reading; item 23, 3.02 points: Take notes while reading), and just one PROB strategy (item 21, 3.20 points: Stop from time to time and think).

Table 9. Distribution of strategy use. 
1. Reread the text to increase understanding

2. Pay close attention to reading

3. Read slowly but carefully

4. Translate from English into my native language

PROB

PROB

PROB

PROB

PROB

GLOB

SUP

6. Use figures, tables, and pictures to increase understanding

7. Think about information in both English and native language

8. Think about what I know

9. Try to guess the meaning of unknown words or phrases

10. Use dictionaries

11. Preview the text before reading

12. Adjust my reading speed

13. Go back and forth to find relationships among ideas

14. Underline and circle information

15. Paraphrase

16. Skim the length and organization of the text

17. Use context clues

18. Check if guesses are right or wrong

19. Use typographical aids like bold face and italics to identify key information GLOB

20. Decide what to read closely and what to ignore

21. Stop from time to time and think

22. Ask myself questions while reading

23. Take notes while reading

24. Preview the text before reading
GLOB

PROB

SUP

GLOB

PROB

SUP

SUP

SUP

GLOB

GLOB

GLOB

3.26

GLOB

PROB

SUP

SUP

GLOB
4.33

4.32

4.31

4.23

4.15

4.08

4.03

3.95

3.90

3.88

3.63

3.59

3.58

3.53

3.42

3.35

3.20

3.20

3.16

3.02

2.93

In order to determine the usage level of reading strategies according to the English language proficiency of the participants, the non-parametric Kruskall-Wallis test was used. This test again indicated that PROB strategies are more frequently employed than the other strategies, and especially by B1 students, who show a mean of 4.36. On the other hand, SUP strategies are used less frequently overall, and particularly by B2 students, who display the lowest score (3.21).

Table 10. Use of reading strategies by proficiency level.

\begin{tabular}{cccc}
\hline & \multicolumn{4}{l}{ Reading strategies } \\
\hline & GLOB & PROB & SUP \\
\hline A1 & 3.55 & 4.13 & 3.59 \\
A2 & 3.47 & 4.34 & 3.48 \\
B1 & 3.49 & 4.36 & 3.45 \\
B2 & 3.22 & 4.08 & 3.21 \\
\hline
\end{tabular}

Figure 3 below shows the use of reading strategies based on the school or field of specialization. As can be seen, the trend seen in previous data persists: PROB strategies are more frequently used than GLOB and SUP strategies. High school graduates obtained the highest score, followed by medicine, dentistry, chemistry, and agriculture students. The participants in the other schools or fields of specialization show high and moderate use of all strategies.

Figure 3. Reading strategy use scores by school or field of specialization. 


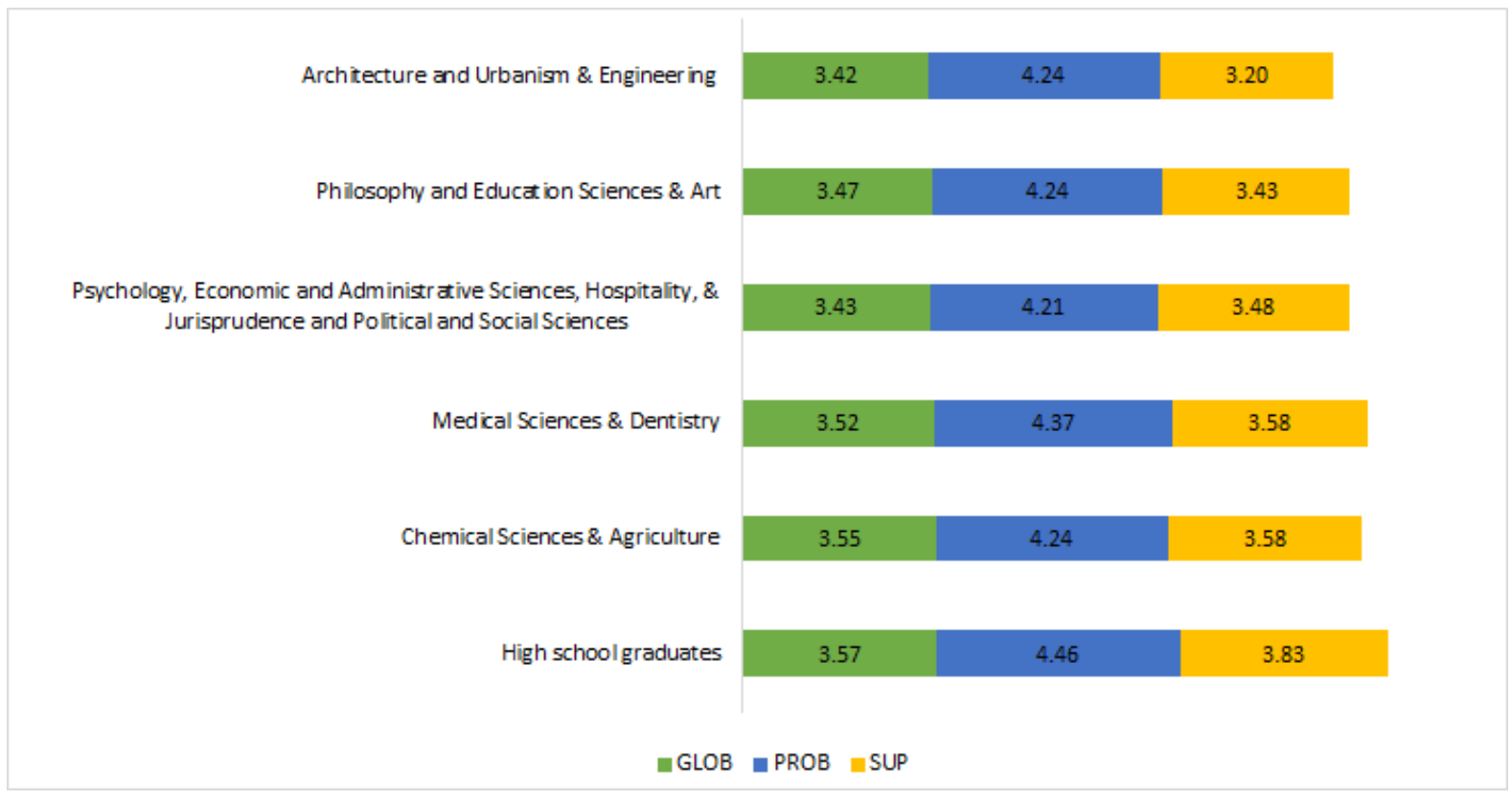

In order to determine whether there are significant differences between schools or fields of specialization, the non-parametric Kruskall-Wallis test was used. The results show that there is a statistically significant association between SUP strategies and high school graduates: they use these strategies far more often than the other participants.

Table 11. Average comparison test of GLOB, PROB, and SUP strategies by school or field of specialization.

\begin{tabular}{llll}
\hline Test Statistics ${ }^{\mathrm{a}, \mathrm{b}}$ & \multicolumn{1}{c}{ GLOB } & \multicolumn{1}{c}{ PROB } & \multicolumn{1}{c}{ SUP } \\
\hline Chi-square & 2.945 & 8.988 & 13.367 \\
$\mathrm{df}$ & 5 & 5 & 5 \\
Asymp. Sig. & 0.708 & 0.110 & 0.020 \\
\hline
\end{tabular}

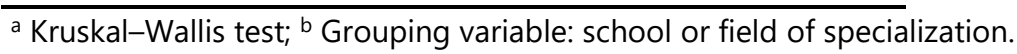

Regarding a correlation between age and reading strategies, the results show that unlike the relationship between age and reading speed and comprehension, the age of students of the Language Department of the University of Cuenca does not show an association with any of the strategies investigated in this study, that is, their use and application are independent of the age of participants.

Table 12. The correlation coefficient between age and reading strategies.

\begin{tabular}{llllll}
\hline & Correlations* & GLOB & PROB & SUP & Age \\
\hline Age & $\begin{array}{l}\text { Spearman's } \\
\text { Rho }\end{array}$ & 0.0069 & -0.0524 & -0.0252 & 1.0000 \\
& Prob $>\mathrm{t}$ & 0.8909 & 0.2962 & 0.6147 & \\
$\mathrm{~N}$ & 400 & 400 & 400 & 400
\end{tabular}

\footnotetext{
Test of H0: GLOB, PROB, SUP, and age are independent. ${ }^{\star}$ Correlation is significant at the 0.05 level.
} 
Regarding gender, Figure 4 below shows that on the whole female participants employ reading strategies more frequently than male participants. Furthermore, PROB strategies again turn out to be the ones that both groups (male and female) use the most. The highest score corresponds to the use of PROB strategies by women (4.38), while the lowest score corresponds to the use of SUP strategies by men (3.25).

Figure 4. Reading strategy differences between genders.

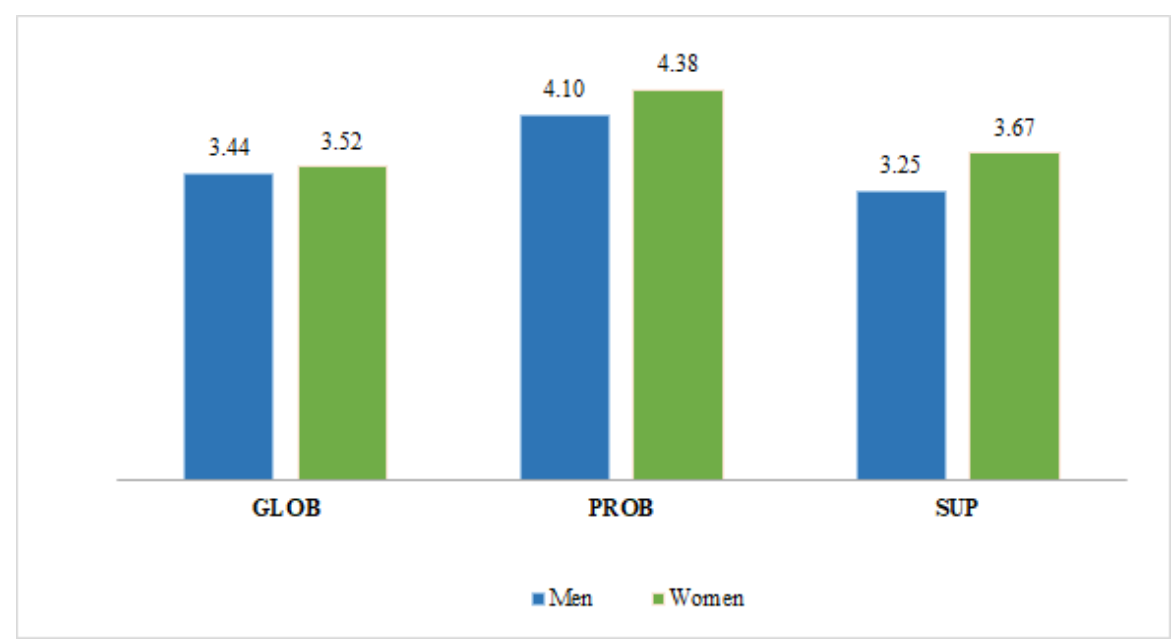

A difference of means test was run in order to uncover significant differences between men and women regarding reading strategies. Table 13 shows that there is a statistically significant association between GLOB strategies and gender: female participants use these strategies more frequently than males. The other two types of strategies are used similarly by both genders.

Table 13. Reading strategy differences between genders.

\begin{tabular}{llll}
\hline Test statistics $^{\mathrm{a}}$ & GLOB & PROB & SUP \\
\hline Mann-Whitney U & $18,174.000$ & $12,903.000$ & $12,915.000$ \\
Wilcoxon W & $30,894.000$ & $25,623.000$ & $25,635.000$ \\
Z & -0.873 & -5.555 & -5.524 \\
Asymp. Sig. (2-tailed) & 0.383 & 0.000 & 0.000 \\
\hline
\end{tabular}

a Grouping variable: Participant gender.

Perusal of Table 14 indicates that the group of language learners who come from private institutions use PROB reading strategies more frequently (4.29) compared to language learners who come from public and charter schools. It is also observed that the participants who completed their high school education in public institutions display, on average, a high score in the use of GLOB (3.54) and SUP (3.55) strategies. 
Table 14. Average use of reading strategies by type of high school education.

\begin{tabular}{l|lc}
\hline \multirow{2}{*}{ High school education } & \multicolumn{2}{|l}{ Reading strategies } \\
\cline { 2 - 3 } & GLOB OB & SUP \\
\hline Public school & 3.54 & 3.55 \\
Private school & 3.30 & 3.38 \\
& & \\
Charter school & 3.51 & 3.47 \\
\hline
\end{tabular}

Regarding the income of participants, this variable is independent of the three types of strategies (GLOB, PROB, SUP) used by the English language learners at the University of Cuenca, meaning that the use of these strategies is not related to having a high or low income (Table 15).

Table 15. Participant income and reading strategies.

\begin{tabular}{llll}
\hline Test statistics $a, b$ & GLOB & PROB & SUP \\
\hline Chi-square & 0.678 & 1.431 & 2.090 \\
df & 3 & 3 & 3 \\
Asymp. Sig. & 0.878 & 0.698 & 0.554 \\
\hline
\end{tabular}

a Kruskal-Wallis Test; ${ }^{b}$ Grouping variable: participant monthly income (USD)

The purpose of this study was to determine the reading speed and reading comprehension level of English language students in the Language Department of the University of Cuenca, as well as the factors that might have an influence on these levels. Our results indicate that these students read $142 \mathrm{wpm}$ and reach $80 \%$ of comprehension, on average. This slow reading speed may be the result of an insufficient reading proficiency acquired before their university studies and/or a sedulous reading of the texts featured in the reading tests, with the purpose of answering the comprehension questions successfully. This is in line with Ngoc (2016), who states that the participants in his study who showed a high level of comprehension decided to "slow down to get more information from the text" (p.8) when taking the reading tests (the participants reached an average of 130 wpm and $72.5 \%$ comprehension). Other similar results were obtained in studies by Wallot et al. (2014) and Borja (1998), in which the participants achieved a low number of wpm but a high percentage of reading comprehension. This slow reading leading to a high level of comprehension has been reported in many other studies (Allen, Jacovina, and McNamara, 2016; Chang, 2010; Fry, 1975; Nuttall, 1996; Stanovich, 1980). Nevertheless, a number of studies (Bowey, 2005; Maluch and Sachse, 2020; Perfetti, Landi, and Oakhill, 2005; Snow, Burns, and Griffin, 1998; Stanovich, 2000) have shown that when a person reads a high number of wpm it is likely that they will reach a high level of comprehension as well. This contradictory assertion might be explained by the reading habit factor: when facing a reading test featuring comprehension questions, those who frequently read books, magazines, online articles, and other texts will not necessarily slow down their reading in order to retain information in their minds to answer those questions correctly (which is what most people tend to do); their reading habit is so regular that even during a test they read in the habitual way they are accustomed to (Beglar, Hunt, and Kite, 2012; Chmykhova, Davydov, and Lavrova, 2014; Mu, 2014; Owusu-Acheaw and Larson, 2014; Rosli et al., 2017). 
Another factor at play may be the English language proficiency level of participants. According to the Education First (EF) English Proficiency Index (2019), Ecuador is ranked 81 out of 100 countries and regions in terms of English skills. This ranking means Ecuadorian students show, on average, very low proficiency in the English language, equivalent to the A1 level of the CEFR. Usually, when students face a reading test featuring vocabulary and grammatical structures they are not familiar with, their reading speed tends to decrease (Cobb, 2008; Fraser, 2007; Student Academic Resource Center, 2017). It appears that there is no set pattern regarding the results of reading speed and comprehension tests, however: in some studies, participants achieve a low number of wpm but a high level of comprehension; in others, they reach a high number of wpm and also a high level of comprehension; and sometimes they obtain a low number of wpm and also a low level of comprehension. It, therefore, seems likely that these results depend on other factors, such as the participants' English proficiency level and their reading habits.

The second research question posed here is about the impact of the use of reading strategies on reading comprehension levels. The data show that the use of any type of strategy (GLOB, PROB, or SUP) has an influence on participants' comprehension, meaning that the more frequently they use these strategies, the better their comprehension. The results regarding the impact of GLOB, PROB, and SUP strategies on the level of comprehension of participants in this study are consistent with the findings of Abdelrahman and Bsharah (2014), Adbullah, (2018), Anderson (1991), Bongratz et al. (2002), Felts (2018), Grabe (2009), Hans and Hans (2015), Hong-Nam (2014), Huang and Nisbet (2014), Par (2020), Pressley (2006), and Uribe-Enciso (2015). These previous studies indicate that the use of reading strategies increases reading comprehension. An important aspect to mention is that the context in which a comprehension test is applied will determine which strategy or strategies are used more. That is to say, if the participants were to read a passage as homework and were told they would have to take a comprehension test the following day, they would surely adopt strategies like taking notes while reading (SUP), underlining and circling information (SUP), using dictionaries (SUP), going back and forth to find relationships among ideas (SUP), among others, because they have enough time to do so. On the other hand, if participants read a passage in class and immediately take a comprehension test (as in this study), they do not have time to employ the same strategies and would likely prefer to reread the text to increase understanding (PROB), pay close attention to reading (PROB), read slowly but carefully (PROB), and/or adjust their reading speed (PROB).

Finally, our third research question deals with sociodemographic factors that may have an effect on reading comprehension, reading speed, and the use of strategies. The following significant results were found:

- Reading speed and comprehension and English proficiency: The results show that participants with the lowest English language level (A1 students) read the fastest, while those who theoretically manage the English language the best (B2 students) read the slowest. These results are in contrast with what commonly tends to occur-that is, advanced L2 students generally tend to read faster than L2 beginners, as corroborated by the findings of Chang and Millet (2013), Maluch and Sachse (2020), Quirk and Beem (2012), Taguchi and Gorsuch (2002), and Taguchi, Takayasu-Maass, and Gorsuch (2004). This contradictory outcome might be explained by the fact that the B2 students who took part in the current study represent only a small proportion of total participants (only 3.5\%), while A1 students embodied $31.25 \%$ of the sample. Another cause might be that most of the A1 participants were students who, besides taking English language courses, were taking other classes in which they frequently had to read academic material and thus were more accustomed to the types of texts presented in the reading test. On the other hand, not all of the B2 participants were university students (the Language Department offers English courses to the general public); they were mainly people aiming to improve their English skills either to get a better job or to apply for a scholarship to study abroad and were not fully involved in an environment in which the constant reading of academic texts is mandatory. Regarding comprehension levels, the results of the A1, A2, and B1 groups were alike (between 79 and 82\%), while the B2 participants showed lower levels of comprehension (66.07\%). Likewise, their reading comprehension results might be explained by the small number of participants belonging to this group of learners.

- $\quad$ Reading speed and comprehension and field of specialization: Comprehension levels were similar across all majors (average $79.88 \%)$. However, the results regarding reading speed are not conclusive because the number of participants in each knowledge area was different. When focusing on the results of groups with similar participant numbers (20-25\% of the sample), we find that those who achieved the fastest reading speeds were in the chemical sciences and agriculture (197.3 wpm), followed by psychology, economic, and administrative sciences, and jurisprudence and the political and economic sciences (156.2 wpm), and finally, the medical sciences and dentistry (110.4 wpm). As can be seen, the major pursued does have an impact on reading speed. These results, however, are in contrast to the findings of De Brito Cunha and Angeli dos Santos (2005), Fregoso (2005), and Navarro et al. (2020), whose studies on university students suggest that there is no specific field of knowledge that may be deemed as a determinant of higher levels of speed or reading comprehension. These studies, however, analyzed the link between reading speed and comprehension in one's mother tongue and the field of specialization. The limited data regarding the relationship between reading speed and/or 
comprehension in English as a foreign language and one's field of specialization does not allow us to suggest any particular reason for the aforementioned results, and further work is needed to shed more light on these results.

- Reading speed and comprehension and age: There was no relationship between the age of participants and their reading speed. The data, however, indicate that there is a negative association between age and reading comprehension. This means that as people get older, their comprehension skills tend to decrease. This is in line with the findings of Hannon and Daneman (2009), Mitzner and Rogers (2006), and Véliz, Riffo, and Arcancibia (2010), who claim that reading comprehension skills are likely to decline with normal aging. This occurs because working memory (the capacity to hold information temporarily) reduces as people get older as a result of neurological and cognitive changes such as metabolic variation, neurochemical alteration, attention, and processing speed reduction, among others (Hannon and Daneman, 2009; Ruiz-Vargas, 2008). These changes are a natural occurrence in all human beings, and cognitive abilities like conceptual reasoning, memory, attention, and processing speed decline gradually over time, being more evident in older adults (Deary et al., 2009; De Beni, Borella, and Carretti, 2007; Harada, Natelson, and Triebel, 2013; Murman, 2015; Pérez, 2005; Ruiz-Vargas, 2008; Sosa, 2016).

- Reading speed and comprehension and prior education: The level of reading comprehension was similar across participants (average of $80.79 \%$ ) regardless of the type of school they attended prior to their university studies-public, private, or charter. The results, however, show that students from private schools read a lot faster (174 wpm) than those from the public (143 wpm) or charter schools $(93 \mathrm{wpm})$. Despite the fact that the number of participants from public, private, or charter schools differs (students from public schools were three times more numerous than the others), several studies corroborate that students from private schools read faster than those going through the public system (Aldazabal, 2019; Carreño, 2000; Cruz, Gálvez-Sobral, and Argueta, 2017; Escurra, 2003; Sánchez, 1987). This might indicate ineffective educational policies by governments of countries like Ecuador in regard to the development and strengthening of the reading skills of public school students (Carreño, 2000; Greany, 1996). This situation is evidenced by the fact that according to the UNESCO Institute for Statistics (UIS) (2017), school children and teenagers in Latin America (most of whom attend public schools) lack basic competency in reading comprehension. Moreover, while in countries like India or France people read 10.7 and 6.9 hours per week, respectively (NOP World Culture Score Index, 2013), in Ecuador-where most students attend public schools—-people read just 1-2 hours per week (INEC, 2012).

- Use of reading strategies and gender: The female participants in this study use reading strategies more frequently than the males. These results are consistent with the findings of Lee (2012), Oxford, Nyikos, and Ehrman (1988), Peart (2017), and Poole (2009). It seems that female students adopt a more positive attitude towards reading and thus may be more thorough readers than male students; consequently, female readers make extensive use of a wider range of strategies (Lee, 2012; Peart, 2017). This might be explained by the findings of Stoet et al. (2013), which support the notion that women have an advantage over men in multitasking; therefore, when facing a reading task, women seem to be able to use different strategies at the same time, consequently outperforming men. In fact, recent studies have shown that the female brain is more active than the male one (Harasty et al., 1997; Xin et al., 2019; Zaidi, 2010), which seems to support the notion that women use reading strategies more than men.

\section{Conclusion}

Studies of reading speed and comprehension highlight the importance of these two aspects of reading skill, which is a key element of knowledge acquisition. Those who read faster and comprehend more than others have an advantage in activities involving interaction between a reader and a text, which might also denote a sizable advantage for good readers in terms of personal goals that could impact their lives (e.g., school achievements or job opportunities). The results of the current research suggest that when faced with a reading speed test (particularly in a foreign language) followed by comprehension questions, participants tend to slow down their reading speed in order to retain as much information as possible and be able to accurately answer the questions. This also results in high use of reading strategies (mainly PROB strategies) because of the little amount of time elapsed between reading the text and answering questions. All of this frequently entails high levels of comprehension but low levels of speed, which is what was observed in the participants in this study: they achieved $80 \%$ comprehension of the texts but their average reading speed was just $142 \mathrm{wpm}$, which is far from the international standard average of a skillful reader in a foreign language (200-250 wpm).

The lack of similar studies in the local context, that is, concerning Ecuadorian university students taking a reading speed and comprehension test in a foreign language, as well as their use of reading strategies, led us to develop procedures for the application of these kinds of tests based on case studies from other countries and other contexts. This adaptation of tools may represent a 
significant limitation of this work. This study is therefore exploratory, and further studies on reading speed, reading comprehension, and the use of reading strategies in English as a foreign language (EFL) context are needed to shed light on the results obtained here. We particularly recommend carrying out studies featuring different ways of administering the reading tests, e.g., recording participants' reading speeds when reading a text out loud or allowing them to read a text at home and testing their comprehension the following day. Differences in speed, comprehension level, and use of strategies are expected with these and/or other variations, which might shed light on the importance of context when assessing reading skills and provide a more comprehensive understanding of their dynamics, with the aim of supporting those who show deficiencies. Furthermore, according to the outcomes of this study a research-based intervention with the aid of English teachers at the University of Cuenca may represent a good step to take to improve the reading speed and comprehension levels of our university students. In order to fulfill this goal, it is necessary to make students aware of the wide range of reading strategies that might help them boost their reading speed and comprehension in a foreign language. This could entail a significant improvement of the student's performance, since being able to read fast and fully comprehend a text usually means that students can more effectively acquire a vast knowledge of different subjects. With regard to English language courses, proficient readers frequently succeed and, when dealing with international examinations to apply for a scholarship, for instance, are those who regularly succeed as well. Therefore, the research-based intervention mentioned above will not only mean support for those with reading difficulties but might also constitute a reference point for future research endeavors on this issue.

Funding: This research received no external funding.

Acknowledgments: The authors want to express their deepest gratitude to Dr. Alan Blackstock because of his unconditional support for the completion of this article.

Conflicts of Interest: The authors declare no conflict of interest.

\section{References}

[1] Abdelrahman, M. S. H. B. \& Bsharah, M. S. (2014). The Effect of Speed Reading Strategies on Developing Reading Comprehension among the 2nd Secondary Students in the English Language. Journal English Language Teaching, 7(6), 168-174.

[2] Abdullah, M. (2018). Reading Speed and Comprehension Enhancement in Hybrid Learning Delivery Mode. Advances in Language and Literary Studies, 9, 25-33.

[3] Aldazabal, E. (2019). Relación entre los procesos lectores y la comprensión lectora de los estudiantes de segundo grado de primaria de una institución educativa estatal y otra privada del distrito de Santa Anita. Master's dissertation. Pontificia Universidad Católica del Perú.

[4] Alessi, S. \& Dwyer, A. (2008). Vocabulary assistance before and during reading. Reading in a Foreign Language, 20(2), $246-263$.

[5] Allen, L. K., Jacovina, M. E., \& McNamara, D. S. (2016). Cohesive features of deep text comprehension processes. In J. Trueswell, A. Papafragou, D. Grodner, \& D. Mirman (Eds.), Proceedings of the 38th Annual Meeting of the Cognitive Science Society in Philadelphia, PA, (pp. 2681-2686). Austin, TX: Cognitive Science Society. Published with acknowledgment of federal support.

[6] Anderson, N. J. (1991). Individual differences in strategy use in second language reading and testing. Modern Language Journal, 75, 460472.

[7] Anderson, R. C. \& Pearson, P.D. (1984). A schema-theoric view of basic processes in reading comprehension. In P. D. Pearson (Ed.). Handbook of Reading Research, (pp. 255-291). New York: Longman.

[8] Barzegar, N. \& Fazilatfar, A. M. (2019). Reading strategies and reading fluency: A case study of reading in a first or second language. Journal of Language Teaching and Research, 10(5), 989-997.

[9] Beale, A. M. (2013). Anne Arundal Community College. Retrieved from www.aacc.ed/ tutoring/file/skimming.pdf

[10] Beglar, D., Hunt, A., \& Kite, Y. (2012). The effect of pleasure reading on Japanese university EFL learners' reading rates. Language Learning, 62, 665-703.

[11] Bongratz, K., Bradley, J., Fisel, K., Crcutt, J., \& Shoemaker, A. (2002). Improving student comprehension skills through the use of reading strategies. Master's dissertation. Saint Xavier University \& Skylight Professional Development.

[12] Borja, A. (1998). Relación entre comprensión lectora y velocidad en alumnos de nivel intermedio de la preparatoria bilingüe ITESM. Master's dissertation. Instituto Tecnológico y de Estudios Superiores de Monterey.

[13] Bowey, J. A. (2005). Predicting Individual Differences in Learning to Read. In M. J. Snowling \& C. Hulme (Eds.), Blackwell handbooks of developmental psychology. The science of reading: A handbook (pp. 155-172). Malden: Blackwell Publishing.

[14] Carrell, P. L. \& Eisterhold, J. C. (1983). Schema theory and ESL reading. TESOL Quarterly, 17(4), 553-573.

[15] Carreño, C. B. (2000). Comprensión de lectura al finalizar primaria en niños peruanos. Master's dissertation. Pontificia Universidad Católica del Perú.

[16] Chang, A. C. S. (2010). The effect of a timed reading activity on EFL learners: Speed, comprehension, and perceptions. Reading in a Foreign Language, 22(2), 284-303.

[17] Chang, A. C. S. \& Millett, S. (2013). Improving reading rates and comprehension through timed repeated reading. Reading in a Foreign Language, 25(2), 126-148.

[18] Cheng, Y. \& Wu, X. (2017). The relationship between SES and Reading Comprehension in Chinese: A Mediation Model. Frontiers in Psychology, 8(672), 1-7. 
[19] Chmykhova, E., Davydov, D., \& Lavrova, T. (2014). The Factors of the Reading Speed: An Experimental Study. The Psychology of Learning, 9, 26-36.

[20] Cobb, T. (2008). Commentary: Response to McQuillan and Krashan (2008). Language Learning and Technology, 12, $109-114$.

[21] Cruz, A., Gálvez-Sobral, A., \& Argueta, B. (2017). ¿Cómo leen los estudiantes de primero primaria, del sector público y privado? Estudio de una muestra de establecimientos. Centro de investigaciones educativas, 35, 90-94.

[22] Cummins, J. (1981). The Cross-Lingual Dimension of Language Proficiency: Implications for Bilingual Education and the Optimal Age Issue. Tesol Quarterly, 14(2), 175-187.

[23] Deary, I., Corley, J., Gow, A., Harris, S., Houlihan, L., Marioni, R., Penke, L., Rafnsson, S., \& Starr, J. (2009). Age-associated cognitive decline. British Medical Bulletin, 92, 135-152.

[24] De Beni, R., Borella, E., \& Carretti, B. (2007). Reading Comprehension in Aging: The Role of Working Memory and Metacomprehension. Aging, Neuropsychology and Cognition, 14(2), 189-212.

[25] De Brito Cunha, N. \& Angeli dos Santos, A. (2005). Comprensión de lectura en universitarios cursantes del 1er año en distintas carreras. Paradigma, 26(2), 99-113.

[26] Emam, A. \& Youssef, A. (2012). Do Females Read Faster than Males? An Empirical Study Using Eye Tracking Systems. International Journal of Computer Science Issues, 9(3), 232-240.

[27] EF English Proficiency Index. (2019). Retrieved from https://www.ef.com/wwen/epi/

[28] Escurra, M. (2003). Comprensión de lectura y velocidad lectora en alumnos de sexto grado de primaria de centros educativos estatales y no estatales de Lima. Persona, 6, 99-134.

[29] Fauzan, J. (2016). Gender Differences in Reading Comprehension Achievement (A Case Study at lain Syekh Nurjati Cirebon). ELT-Echo, $1(1), 27-41$.

[30] Felts, T. (2018). Reading Comprehension Strategies 1 Instructional Strategies for Improving Reading Comprehension. Retrieved from https://www.researchgate.net/publication/329651899_READING_COMPREHENSION_STRATEGIES_1

_Instructional_Strategies_for_Improving_Reading_Comprehension

[31] Francisco, L. \& Madrazo, C. (2019). Reading habits, reading comprehension, and academic performance of grade $\mathrm{V}$ of pupils. The Asian ESP Journal, 15(2), 138-165.

[32] Fraser, C. A. (2007). Reading rate in L1 Mandarin and L2 English across five reading tasks. The Modern Language Journal, $91,372-394$.

[33] Fregoso, G. (2005). Los problemas del estudiante universitario con la lectura: Un estudio de caso. Guadalajara: Centro Universitario de Los Altos.

[34] Fry, E. (1975). Reading drills for speed and comprehension. Providence R.I.: Jamestown Publishers.

[35] Goh, C. C. M. \& Kwah, P. F. (1997). Chinese ESL students' learning strategies: A look at frequency, proficiency, and gender. Hong Kong Journal of Applied Linguistics 2(1), 39-53.

[36] Grabe, W. (2009). Reading in a Second Language: Moving from Theory to Practice. Cambridge: Cambridge University Press.

[37] Greaney, V. (1996). Promoting reading in developing countries. Newark D.E.: International Reading Association.

[38] Halpern, D. F. (2014). Thought and knowledge: An introduction to critical thinking (5th ed.). New York: Taylor \& Francis Group.

[39] Hannon, B. \& Daneman, M. (2009). Age-Related Changes in Reading Comprehension: An Individual-Differences Perspective. Experimental Aging Research, 35(4), 432-456.

[40] Hans, A. \& Hans, E. (2015). Different comprehension strategies to improve students' reading comprehension. International Journal of English Language Teaching, 3(6), 61-69.

[41] Harada, C., Natelson, M., \& Triebel, K. (2013). Normal Cognitive Aging. Clinics in Geriatric Medicine, 29(4), 737-752.

[42] Harasty, J., Double, K. L., Halliday, G. M., Kril, J. J., \& McRitchie, D. A. (1997). Language-associated cortical regions are proportionally larger in the female brain. Arch Neurol, 54(2), 171-176.

[43] Hermida, J. (2009). The Importance of Teaching Academic Reading Skills in First-Year University Courses. The International Journal of Research and Review, 3, 20-30.

[44] Hong-Nam, K. (2014). ELL high school students' metacognitive awareness of reading strategy use and reading proficiency. TESL-EJ, 18(1), $1-16$.

[45] Hong-Nam, K. \& Leavell, A. G. (2006). Language learning strategy use of ESL students in an intensive English learning context. The system, 34(3), 399-415.

[46] Huang, J. \& Nisbet, D. (2014). The relationship between reading proficiency and reading strategy use: A study of adult ESL learners. J. of Adult Education, 43(2), 1-11.

[47] Hussein, A. (2018). The Relationship between Gender and Reading Comprehension at College Level. Journal of Basrah Research: The Humanities Sciences, 42(6), 426-442.

[48] INEC. (2012). Hábitos de lectura en Ecuador. Retrieved from www.ecuadorencifras.com

[49] Iqbal, M., Noor, M., Muhabat, F., \& Kazemian, B. (2015). Factors Responsible for Poor English Reading Comprehension at Secondary Level. Communication and Linguistics Studies, 1(1), 1-6.

[50] Ismail, S. A. M. M., Karim, A., \& Mohamed, A. R. (2018). The role of gender, socioeconomic status, and ethnicity in predicting ESL learners' reading comprehension. Reading \& Writing Quarterly, 34(6), 457-484.

[51] Laufer, B. (1989). What percentage of text-lexis is essential for comprehension? In C. Lauren \& M. Nordman (Eds.), Special Language: From Humans Thinking to Think Machines (pp. 316-323). Clevedon \& Philadelphia: Multilingual Matters Ltd.

[52] Lee, M-L. (2012). A Study of the Selection of Reading Strategies among Genders by EFL College Students. Procedia - Social and Behavioral Sciences, 64, 310-319.

[53] López, M. (2013). La fluidez lectora en el primer ciclo de educación primaria. Bachelor's dissertation. Universidad de Valladolid, España.

[54] Maluch, J. \& Sachse, K. (2020). Reading in Developing L2 Learners: The Interrelated Factors of Speed, Comprehension, and Efficiency across Proficiency Levels. TESL-EJ, 24(1), 1-17. 
[55] Miñoza, M. \& Montero, M. (2019). Reading comprehension level among intermediate learners. Science International (Lahore), 31(3), 561568.

[56] Mitzner, T. \& Rogers, W. (2006). Reading in the Dark: Effects of Age and Contrast on Reading Speed and Comprehension. Human factors, 48, 229-240.

[57] Mokhtari, K. \& Reichard, C.A. (2002). Assessing Students' Metacognitive Awareness of Reading Strategies. Journal of Educational Psychology, 94(2), 249-259.

[58] Mokhtari, K. \& Sheorey, R. (2002). Measuring ESL students' awareness of reading strategies. Journal of Developmental Education, 25, 2-10.

[59] Mu, H. (2014). Does Extensive Reading Promote Reading Speed? The Reading Matrix, 14(1), 16-25.

[60] Murman, D. (2015). The Impact of Age on Cognition. Seminars in Hearing, 36(03), 111-121.

[61] Navarro, F., Ávila, N., Calle-Aragno, L., \& Cortés, M. (2020). Lectura, escritura y oralidad en perfiles de egreso de educación superior: Contrastes entre instituciones y carreras. Calidad en la Educación, 52, 170-204.

[62] Nation, P. (2001). Learning Vocabulary in Another Language. New York: Cambridge University Press.

[63] Nation, P. (2005). Reading faster. PASAA, 36, 21-37.

[64] Nation, I. S. P. (2009). Teaching ESL/EFL Reading and Writing. New York: Routledge.

[65] National Reading Panel. (2000). Teaching children to read: An evidence-based assessment of the scientific research literature on reading and its implications for reading instruction. Retrieved from https://www.nichd.nih.gov/sites/default/files/publications/pubs/nrp/ Documents/report.pdf.

[66] Nicholson, T. \& Tan, A. (1999). Word identification processes. In G. B Thompson, T. Nicholson (Eds.) Learning to read: Beyond phonics and whole language (pp. 150-173). New York: Teachers College Press.

[67] Ngoc, T. T. (2016). EFL Reading Speed and Comprehension. IOSR Journal of Humanities and Social Science (IOSR-JHSS) 21(10), 1-10.

[68] NOP World Culture Score Index (2013). Retrieved from http://chartsbin.com/view/32136.

[69] Nuttall, C. (1996). Teaching reading skills in a foreign language. Bath: Heinemann.

[70] Owusu-Acheaw, M. \& Larson, A. G. (2014). Reading Habits Among Students and Its Effect on Academic Performance: A Study of Students of Koforidua Polytechnic. Library Philosophy and Practice (e-journal), 1130. Retrieved from http://digitalcommons.unl.edu/libphilprac/1130.

[71] Oxford, R., Nyikos, M., \& Ehrman, M. (1988). Vive la Différence? Reflections on Sex Differences in Use of Language Learning Strategies. Foreign Language Annals, 21(4), 321-329.

[72] Par, L. (2020). The Relationship between Reading Strategies and Reading Achievement of the EFL Students. International Journal of Instruction, 13(2), 223-238.

[73] Peart, S. M. (2017). L2 Reading: Strategies and Gender Preferences in the Foreign Language Classroom. Lenguaje y textos, $45,17-27$.

[74] Pereira, S. \& Ramírez, J. (2006). Adaptación de un instrumento para evaluar el conocimiento de estrategias metacognitivas de estudiantes universitarios venezolanos al leer textos académicos en inglés. Laurus, 12, 148-169.

[75] Pérez, V. (2005). El deterioro cognitivo: una mirada previsora. Revista Cubana de Medicina General Integral, 21(1-2).

[76] Perfetti, C. A., Landi, N., \& Oakhill, J. (2005). The Acquisition of Reading Comprehension Skill. In M. J. Snowling \& C. Hulme (Eds.) The Science of Reading: A Handbook (pp. 227-247). Oxford: Blackwell.

[77] Poole, A. (2005). Gender differences in reading strategy use among ESL college students. Journal of College Reading \& Learning, 36(1), 720.

[78] Poole, A. (2009). The Reading Strategies Used by Male and Female Colombian University Students. Profile Issues in Teachers' Professional Development, (11), 29-40.

[79] Pressley, M. (2006). Reading Instructions that Works (third edition). New York: Guilford Press.

[80] Quirk, M. \& Beem, S. (2012). Examining the relations between reading fluency and reading comprehension for English language learners. Psychology in the Schools, 49(6), 539-553.

[81] Reilly, D., Neumann, D. L., \& Andrews, G. (2019). Gender differences in reading and writing achievement: Evidence from the National Assessment of Educational Progress (NAEP). American Psychologist, 74(4), 445-458.

[82] Rosli, N. A., Razali, N. F., Zamil, Z. U. A., Noor, S. N. F. M., \& Baharuddin, M. F. (2017). The Determination of Reading Habits among Students: A Concept. International Journal of Academic Research in Business and Social Sciences, 7(12), 791-798.

[83] Ruiz-Vargas, J. (2008). Envejecimiento y memoria: ¿cómo y por qué se deteriora la memoria con la edad? Revista Española de Geriatría y Gerontología, 43(5), 268-270.

[84] Sánchez, H. (1987). Lectura: investigaciones en el Perú. Lima: Inide.

[85] Schutz, D. (2010). Misunderstanding Reading Comprehension: Implications for Instruction and Testing. SSRN Electronic Journal, 1-5.

[86] Segalowitz, N. S. \& Segalowitz, S. J. (1993). Skilled performance, practice, and the differentiation of speed-up from automatization effects: Evidence from second language word recognition. Applied Psycholinguistics, 14, 369-385.

[87] Septiarini, T., Rahmat, A., \& Darmahusni. (2018). The Relationship Between Reading Habits and Reading Comprehension of English Department in UNTIRTA. Journal of English Language Studies, 3(2), 178-191.

[88] Shihab, I. (2011). Reading as Critical Thinking. Asian Social Science, 7(8), 209-218.

[89] Snead, B. (2005). Research Results for AceReader Study at CFS Elementary School, Lakewood, CO. National Association of Street Schools, Denver, CO, USA.

[90] Snow, C. E. (2002). Reading for understanding: Toward an R\&D program in reading comprehension. Santa Monica, C.A.: RAND Corporation.

[91] Snow, C. E., Burns, M. S., \& Griffin, P. (1998). Preventing reading difficulties in young children. Washington, D.C.: National Academy Press.

[92] Sosa, M. J. (2016). Deterioro cognitivo en la vejez ¿Fenómeno normal? Monograph. Universidad de la República Uruguay.

[93] Sparks, R., Patton, J., Ganschow, L., Humbach, N., \& Javorsky, J. (2008). Early First-Language Reading and Spelling Skills Predict Later Second-Language Reading and Spelling Skills. Journal of Educational Psychology, 100(1), 162-174.

[94] Stanovich, K. E. (1980). Toward an Interactive-Compensatory Model of Individual Differences in the Development of Reading Fluency. Reading Research Quarterly, 16(1), 32-71. 
[95] Stanovich, K. E. (2000). Progress in understanding reading: Scientific foundations and new frontiers. New York: Guilford.

[96] Stoet, G., O'Connor, D., Conner, M., \& Laws, K. (2013). Are women better than men at multitasking? BMC Psychology, 1(18), 1-10.

[97] Student Academic Resource Center. (2017). Identifying Problems that Lead to Slow Reading. https://sarconline.sdes.ucf.edu/wpcontent/uploads/sites/19/2017/07/ldentifying_Probl ems_That_Lead11.pdf

[98] Suhana, A., \& Haryudin, A. (2017). The Effects of Reading Habit towards Students' Reading Comprehension at Private Senior High School in Purwakarta. ELTIN Journal, Journal of English Language Teaching in Indonesia, 5(2), 57-70.

[99] Taguchi, E. \& Gorsuch, G. J. (2002). Transfer effects of repeated EFL reading on reading new passages: A preliminary investigation. Reading in a Foreign Language, 14(1), 43-65.

[100] Taguchi, E., Takayasu-Maass, M., \& Gorsuch, G. J. (2004). Developing reading fluency in EFL: How assisted repeated reading and extensive reading affect fluency development. Reading in a Foreign Language, 16(2), 70-96.

[101] UNESCO Instituto de Estadística (IUS). (2017). Más de la Mitad de los Niños Adolescentes en el Mundo No Está Aprendiendo. Fact sheet No. 46. Montreal: UNESCO.

[102] Uribe-Enciso, O. (2015). Improving EFL students' performance in reading comprehension through explicit instruction in strategies. Rastros Rostros, 17(31), 37-52.

[103] Vallés, A. (2002). Inteligencia emocional: ¿personalidad o inteligencia? Revista Peruana de Psicología (12), 19-34.

[104] Vallés, A. (2005). Comprensión lectora y procesos fonológicos. Liberabit (11), 49-61.

[105] Véliz, M., Riffo, B., \& Arancibia, B. (2010). Envejecimiento cognitivo y procesamiento del lenguaje: cuestiones relevantes. Revista de lingüística teórica y aplicada, 48(1), 75-103.

[106] Wallot, S., O'Brien, B. A., Haussmann, A., Kloos, H., \& Lyby, M. S. (2014). The role of reading time complexity and reading speed in text comprehension. Journal of Experimental Psychology: Learning, Memory, and Cognition, 40(6), 1745-1765.

[107] Willingham, M. (2017). Improving Reading Fluency - 15 minutes per day. A Case Study Using AceReader to Improve Students Silent Reading Skills. AceReader white paper.

[108] Xin, J., Zhang, Y., Tang, Y., \& Yang, Y. (2019). Brain Differences Between Men and Women: Evidence from Deep Learning. Frontiers in Neuroscience, 13, 1-10.

[109] Yeh, M. L. \& Chen, H. H. (2005). Effects of an educational program with interactive videodisc systems in improving critical thinking dispositions in Taiwan. International Journal of Nursing Studies, 42, 333-340.

[110] Zaidi, Z. (2010). Gender Differences in Human Brain. The Open Anatomy Journal, 2, 37-55.

\section{Appendix 1 \\ Readings selected for the tests \\ A1}

1

An "ant farm" is a toy. It is almost like a pet. Kids can see where the ants live. They can see how they work and eat.

Milton Levin created the first ant farm. He was curious. He watched ants at a picnic. Then he had an idea. In 1956, he made the "farm." It was a hit.

People have sold more than 25 million farms. They are easy to care for. They are also fun to watch. The toy remains popular.

Two other toys came out the same year. These were Play-Doh and Yahtzee.

2

Do you like movies? George Lucas does. He wanted to race cars, but he got hurt. He went to film school. He worked on other people's movies. Then he made his own. "Star Wars" came out in 1977. It made the most money any film ever had. It also changed the way we watch movies. It had a lot of action and special effects. Now a lot of people use them. They also use computers to help create what we see.

\section{3}

Mercury is the closest planet to the Sun. It is the smallest planet in the solar system. Pluto is no longer called a planet. It is too small. Mercury has a day side and a night side. The dayside is the hottest place in the solar system. It takes 88 days to move around the sun and 59 days to spin on its own axis. The surface of Mercury is full of craters.

\section{A2}

4

Tea is the second most popular drink in the world; the first is plain water. The tea plant is native to many countries, including China, and there are many stories about how people started drinking it. One story tells of a famous Chinese emperor. His name was Shen Nong, and he lived about 2,000 years ago. He knew a lot about plants and medicine. In fact, he told his subjects to boil their water before drinking it because he thought it was healthier. He, himself, drank hot water in his garden every day. 
One day a leaf blew into his cup. It smelled good, so he drank some of it. He liked the taste, and it made him feel better. He told others to try it, and they liked it, too.

The first written description of tea as a deliberately made drink came in 350 A.D. The Chinese writer Kuo P'o' ut it in a new dictionary. He said it was a "beverage made from boiled leaves." At that time, people mixed the tea leaves in water with ginger, orange, or other plants. They used it mostly as medicine for the stomach and nerves. In some places in China, people also pressed the leaves into a brick. They used it for money.

5

You know that the United States was born on July 4, 1776. But did you know that the U.S. Navy also has a birthday? It's October 13,1775 . How can the Navy be older than the United States?

The American colonies depended on the sea for their living. Some people built ships. Others traded goods when foreign ships came into port. When the Revolutionary War started, the British attacked the ports. Many people struggled to survive. If the colonies were going to win the war and become independent, they needed ships of their own to fight the British.

On October 13, 1775, the Second Continental Congress bought two ships. It wasn't much, but it was the beginning of the Navy as we know it.

6

Earth has an atmosphere. Not every planet does. It is the air around us. The layers form a "blanket." They protect us from the Sun. They also protect us from the cold of space.

Air contains many parts. It has nitrogen, oxygen, and small pieces of dust. Animals breathe oxygen. They get rid of carbon dioxide. Plants breathe carbon dioxide and get rid of oxygen. We find both in the air. We also find small amounts of other things. These can be natural or man-made.

The atmosphere is held in place by the pull of the Earth's gravity. It extends to about 1,250 miles above the surface of the planet.

B1

7

Professional football was first played around 1895. In 1920 the American Professional Football Association was formed. The APFA handed out franchises right and left and it ended up with 23 terms. One year later, it charged again and in 1922. It was renamed the National Football League.

The NFL was limited to only ten terms which then grew to 16 in 1970 the NFL teams merged with 10 American Football League (AFL) teams to form one league with two divisions. The result was the first modern professional football association.

In the 1980s, further, expansion was processed, and by the 1993-1994 NFL season approval was given for a thirty-team league. The next step towards the growth of the league was to separate the NFL into eight different divisions, each with four teams.

\section{8}

Today Crayola Crayons are everywhere, but that wasn't always the case. In 1885, two cousins. Edwin Binney and C. Harold Smith formed a business partnership. In 1900, they purchased a stone mill in Easton, Pennsylvania, and began to produce slate pencils for schools.

With schools accounting for a large percentage of their business the cousins started to research non-toxic and colorful media kids. They had already invented a new wax crayon which was used to draw on creates and barriers, but it was loaded with carbon black that it made it too toxic for children.

Still, the pair were confident that the pigment and wax mixing techniques they had developed could be adapted for a variety of safe colors.

In 1903, They introduced a new brand of crayons that contained both superior color and child-friendly ingredients. The name "Crayola" was coined by Binney's wife Alice, it comes from "craie" the French word for chalk, and "ola" for fat/wax-like. There were originally only eight colors: black, blue, brown, green, orange, red, violet, and yellow. 
Now Crayola has become the crayon standard and it boats 23 reds, 20 greens, 19 blues, 16 purples, 14 oranges, 11 browns, 8 yellows, 2 grays, 2 coppers, 2 blacks, 1 white, 1 silver, 1 gold.

\section{9}

The atmosphere is made up of many gases. Some of these are nitrogen, oxygen, and carbon dioxide. It also has layers. Each one has different properties.

The troposphere reaches from the ground to 12 kilometers high. It is the region where weather occurs. It contains clouds rain snow and storms. The stratosphere reaches from 12 to 50 kilometers high. The ozone layer in this region absorbs ultraviolet radiation. This makes it possible for life to exist on the planet. The atmosphere or "middle atmosphere" reaches from 50 to 80 kilometers high. The temperature drops sharply in this region. Most meteorites burn up here. The thermosphere extends above 80 kilometers high. The air is very thin here and very hot -up 1800 degrees Celsius. It has no outer limit.

The thermosphere is divided into two regions. The lonosphere reaches 80 to 550 kilometers above Earth's surface. lons in this region reflect radio waves back to Earth. This is also the region that produces the aurora borealis, or the "Nathen Lights" The exosphere is the "Outer Atmosphere" It extends from 550 kilometers high out into space. Artificial satellites orbit in this region.

B2

10

When we fall victim to difficulties that cannot be avoided, we often think of Murphy's law. If anything can go wrong. It will. What we may not realize is that Murphy's law is not just a fictitious character from an obscure period of our history. But he was an actual person whose actions gave rise to the term.

The term Murphy's law was invented at Edwards Field, California in 1949 and was named after Captain Edward E. Murphy. Murphy was a development engineer on the Air Force Project MX981, which was designed to see how much sudden deceleration a person can withstand in a crash, by conducting research on rockets sleds. Upon discovery one day that a technician, whose name has long since been lost to history, had wired a piece of equipment incorrectly, Murphy cursed the technician and said "if there any way to do things wrong he will "during the testing a list of "laws" was being completed, and this one was included and entitled "Murphy law".

A few weeks later, in a press conference Murphy's superior, Colonel J.P Stapp credited his program's good safety record to planning for Murphy's law.

\section{1}

Do you know the name, Randy Kerr? Maybe not. But you do know what he did.

Polio is a disease. It is caused by a virus. It enters through the nose and mouth and affects the body's nerves and muscles. People can become paralyzed. They may also have trouble breathing or even die. It used to be very common. By 1954 there were about 50.000 new cases in the United States alone each year.

The virus mostly hit young children. Parents were scared and they pulled their children from school. But people found that adults could get it too. President Franklin Roosevelt got it when he was an adult.

Many scientists tried to find out how the virus worked. They wanted to create a way to prevent people from getting the disease. Two men, Jonas Salk and Albert Sabin created vaccines. The Salk vaccine was the first to be tried. It was April 26th, 1954. 6-yearold Randy Kerr was the first in the line to get the shot. He said it barely hurt. It also worked. Now the polio is almost unknown in the US.

12

The solar system is the name we give to our Sun and the planets that orbit it. The Sun is all the center. Mercury is the closest planet to the Sun and Neptune is the farthest away. Pluto used to be considered a planet, but it has gone through several names changes over the years. Today, it is thought to be too small to be a true planet. But that may change again. The inner planets. Are Mercury, Venus, Earth, and Mars. They all have rocky surfaces. The outer planets are Jupiter, Saturn, Uranus, and Neptune. They may or may not have a solid core, however, they all have layers of gas around them. Pluto is also rocky it may be a captured asteroid. It has at least five of its own moons. All the planets except for Mercury and Venus, have at least one moon orbiting them. 
In between Mars and Jupiter is the main asteroid belt. There are thousands of small, rocky bodies in this region. Some people think these may be part of a planet that broke up because of Jupiter's enormous gravity. Others feel that they are part of a planet that never formed, for the same reason. There is another region of asteroids beyond Pluto, called the Kuiper belt. It contains many more than the asteroid belt. It may also serve as the origin for comets.

\section{Appendix 2 \\ Mokhtari and Sheory Survey of Reading Strategies (SORS) (2002)}

The purpose of this survey is to collect information aboul the various techniques you use when you read academic materials in Engliab (C.g, reading textborks for tumework or ecaminations, reading journul articles, ete.).

All the items below refer to your reading of college-related academic materials (such as textbooks, not newspapers or magarinefi). Each statement is followed by five numbers, $1,2,9,4$, and 5 , and earls number means the following:

' 1 ' means that 'I never or almost never do this'.

"2' means that ' 1 do this only occasionally'.

' 9 means that 'I sometimes do this'. (About $50 \%$ of the time.)

"4' means that 'I usually do this'.

'5' means that '1 always or almost always do this'.

After reading each statement, circle the number $(1,2,3,4$, or 5) which appties to you. Note that there are no right or wrong responses to any of the itrms on this survey.

\begin{tabular}{|c|c|c|c|c|c|c|c|}
\hline Category & & Statemernt & Never & & & & Nways \\
\hline GLOB & 1. & 1 have a purpose in mind when I read. & 1 & $y$ & 3 & 4 & 5 \\
\hline SUP & 2 & I take notes while reading to belp ine understand what I read. & 1 & 2 & 3 & 4 & 3 \\
\hline G.OB & 3. & 1 think about what $1 \mathrm{know}$ to help me understand what 1 read. & 1 & 2 & 3 & 4 & 3 \\
\hline GLOB & 4. & 1 take an overall view of the text to see what it is about before reading it. & 1 & 2 & 3 & 4 & 5 \\
\hline St/P & 5. & $\begin{array}{l}\text { When text becomes difficulf, I read aloud to help me } \\
\text { understand what I read. }\end{array}$ & 1 & 2 & 3 & 4 & 5 \\
\hline GLOB & 6. & It think about whether the content of the text fits my reading purpose. & 1 & 2 & 3 & 4 & 3 \\
\hline PROB & 7. & 1 reat slowily and carefully to make stare I understand what I am reading. & 1 & 2 & 3 & 4 & 5 \\
\hline GLOB & 8. & $\begin{array}{l}\text { I review the text first by noting its chatarieristics like length } \\
\text { and organization. }\end{array}$ & 1 & 2 & 3 & 4 & 5 \\
\hline PROB & 9. & I try to get back on track when I lose concentration. & 1 & 2 & 3 & 4 & 5 \\
\hline$\$ E P$ & 10. & I underline or circie information in the text to help me remember it. & 1 & 2 & 3 & 4 & 5 \\
\hline PROB & 11. & I adjust my reading speed according to what I am teakling: & 1 & 9 & 3 & 4 & 5 \\
\hline GLOB & 12. & When reading, I decide what to read dosely and what to ignore. & 1 & 2 & 3 & 4 & 5 \\
\hline$S U P$ & 13. & $\begin{array}{l}\text { I use reference materials (e.g., a dictionary) to help me understand } \\
\text { what I read. }\end{array}$ & I & 2 & 3 & 4 & 5 \\
\hline PROB & 14. & When text becomes difficult, I pay doser attention to what I am reading. & 1 & 2 & 3 & 4 & 5 \\
\hline GLOB & 15. & I use tables. figures, and pictures in text to increase my understanding. & 1 & 2 & 3 & 4 & 5 \\
\hline PROB & 16. & 1 stop from time to time and think abeat what 1 ant reading. & 1 & 2 & 3 & A & 5 \\
\hline GLOB & 17. & I use context clues to help me better undersiand what I am reading. & 1 & 2 & 3 & 4 & 5 \\
\hline$S U P$ & 18. & $\begin{array}{l}\text { I paraphrase (restate ideas in my own words) to better understand } \\
\text { what I read. }\end{array}$ & 1 & 2 & 3 & 4 & 5 \\
\hline PROB & 19. & I try to picture or visualize information to help retnember what 1 read. & 1 & 2 & 3 & 4 & 5 \\
\hline GLOB & 20. & $\begin{array}{l}1 \text { use typographical features like bold face and italios to identify } \\
\text { key information. }\end{array}$ & 1 & 2 & 3 & 4 & b \\
\hline GLOB & 21. & 1 critically amalyze and evaluate the information peesented in the text. & 1 & 2 & 3 & 4 & 5 \\
\hline$S U P$ & 22. & I go back and forth in the text to find relationships among ideas in it. & 1 & 2 & 3 & 4 & 5 \\
\hline CLOOH & 23. & 1 check my understanding when 1 come across new information. & 1 & 2 & 3 & 4 & 5 \\
\hline GLOB & 24. & I try to guess what the content of the text is about when I read. & $t$ & 2 & 3 & 4 & 5 \\
\hline PROB & 25. & When text becomes difficult, I retead it to incresse ayy understanding. & 1 & 2 & 8. & 4 & 5 \\
\hline SUP & 26. & I ask myself queations 1 like to have answered in the text. & 1 & 2 & $\$$ & 4 & 5 \\
\hline GLOB & 27. & 1. check to see if my guesses about the text are right or wrong. & 1 & 2 & 3 & 4 & 5 \\
\hline PROB & 28: & When I read, I guess the meaning of unknown words or phrases. & 1 & $y$ & 3 & 4 & 5 \\
\hline Sets & 29. & When reading, 1 translate from English into my naive language. & 1 & 2 & s. & 4 & 5 \\
\hline sufp & 30. & When reating, 1 think about information in both English and my & 1 & 2 & 3 & 4 & 5 \\
\hline
\end{tabular}

